
СФЕРИ ПОСЛУГ В УМОВАХ ОСВІТНЬО-ВИРОБНИЧОГО КЛАСТЕРУ

inozemnyh mov u serednih navchalnyh zakladah [Methods of teaching foreign languages in secondary schools]. Kyiv, pp.72-90.[in Ukrainian].

5. La Forge, P. G. (1979). "Reflection in the Context of Community Language Learning", English Language Teaching Journal. No. 33 (4), pp. 247254. [in English].

6. Samimy, K. K. (1989). “A Comparative Study of
Teaching Japanese in the Audio-Lingual Method and the Counseling-learning Approach". The Modern Language Journal. No. 73 (11), pp. 169-177. [in English].

7. Samimy, K. K. and Rardin, J. P. (1994). "Adult Language Learners" Affective Reactions to Community Language Learning: A Descriptive Study", Foreign Language Annals. No. 27 (3), pp.379-390. [in English].

Стаття надійшла до редакції 16.04.2019

УДК 377.36:658.64

DOI:

Ліна Короткова, кандидат педагогічних наук, директор Державного навчального закладу "Запорізьке вище професійне училище моди і стилю”

\title{
ЗМІСТ ФУНКЦІОНАЛЬНИХ КОМПОНЕНТІВ ПРОФЕСІЙНОЇ ПІДГОТОВКИ МАЙБУТНІХ ФАХІВЦІВ СФЕРИ ПОСЛУГ В УМОВАХ ОСВІТНЬО- ВИРОБНИЧОГО КЛАСТЕРУ
}

У статті наголошено на важливості якісного змістового наповнення професійної підготовки майбутніх фахівців сфери послуг з урахуванням сучасних галузевих тенденцій. На основі аналізу професійноі діяльності робітників швейної промисловості в умовах освітньо-виробничого кластеру до складових змісту професійної підготовки віднесено предметно-понятійний, технологічний, праксиологічний, культурологічний, естетичний, морально-етичний, психологічний, екологічний, ресурсозбереження й енергоефективності, інформативно-комунікаційний компоненти.

Ключові слова: майбутні фахівці; сфера послуг; зміст професійної підготовки; функціональні компоненти.

Jim. 5.

Lina Korotkova, Ph.D.(Pedagogy), Director of the State Educational Institution "Zaporozhzhya Higher Professional School of Fashion and Style"

\section{CONTENTS OF FUNCTIONAL COMPONENTS OF PROFESSIONAL TRAINING OF FUTURE SERVICE SPECIALISTS WITHIN THE FRAMEWORK OFTHE EDUCATIONAL PRODUCTION CLUSTER}

The article emphasizes the importance of qualitative content filling of the professional training of future specialists in the field of services in the light of current industry trends. On the basis of the analysis of the professional activity of the employees of the garment industry in the conditions of the educational and production cluster, ten functional components are classified into the components of the content of professional training. The subject-concept component allows students to master the professional terminology perfectly, which is a prerequisite for the qualitative mastering of the educational material. The technological component involves provision of future specialists with scientific and technical information on the use of innovative technologies for the production of clothing, information on the leading trends in the garment industry. The praxiological component facilitates the formation of skills to operate effectively in new, uncertain, problem situations, activating the positive needs of an individual and maximizing the neutralization of the needs of a negative nature. The cultural component is considered as a complex of didactic and educational means aimed at the socialization of a person, development of spiritual values and traditions of the country. The aesthetic component involves engaging students into the world of art, developes and cultivates the ability of intellectual perception, enriches the individual experience of worldview. The psychological component ensures possession of the basics of psychology, methods of non-verbal communication, necessary for organization and effective interaction in professional activity. The ecological component involves obtaining information on environmentally friendly modern technologies and materials. The component of resource saving and energy efficiency is aimed at the efficient use of raw materials and basic materials. The informational and communicative component contributes to generalization, systematization, structuring of the received data, to give them new forms and images.

Keywords: future specialists, service industry, a content of professional training, functional components.

П остановка проблеми. Сучасний рівень розвитку суспільства, прискорення темпів науково-

технічного прогресу, інтенсифікація економічного зростання, збільшення обсягів виробництва продукції та послуг зумовлює необхідність 

СФЕРИПОСЛУГ В УМОВАХ ОСВІТНЬО-ВИРОБНИЧОГО КЛАСТЕРУ

формування професіоналів, які б могли у своїй професійній діяльності поєднувати глибокі фундаментальні теоретичні знання і практичну підготовку з постійно зростаючими вимогами споживачів послуг.

Перш за все, потребують усунення такі перешкоди, як дисбаланс на ринках праці та освітніх послуг; відсутність налагодженої системи партнерських відносин між системою професійної (професійно-технічної) освіти та виробництвом, державними і місцевими органами влади, науковцями й громадськими організаціями; невідповідність навчально-матеріальної бази закладів професійної освіти сучасним технологіям виробництва; недосконалість нормативного забезпечення взаємовідносин між навчальними закладами та споживачами освітніх послуг.

Для якісної професійної підготовки майбутніх фахівців важливе значення має їі змістове наповнення, що враховує сучасні галузеві тенденції, зміни в організації праці працівників, а також соціально-психологічні аспекти їхньої професійної діяльності.

Аналіз останніх досліджень і публікацій. У науковій літературі зміст професійної підготовки розглядається як дидактично перероблений, науково обгрунтований методичний та дидактичний навчальний матеріал, засвоєння якого забезпечує здобуття освіти і кваліфікацій згідно з освітньо-кваліфікаційними рівнями [5]. Методологічною основою визначення змісту професійної освіти $є$ загальнолюдські, духовні і національні цінності, сконцентрованість на актуальних і перспективних інтересах особистості. Сучасними дослідниками підкреслюється пріоритетність формування прикладних вмінь на базі сучасних наукових знань, що визначає такі особливості процесу професійної підготовки як нелінійність, варіативність, модульність, індивідуально зорієнтований спосіб засвоєння змісту підготовки $[1,83]$. 3 позицій системного підходу можна виділити декілька рівнів формування змісту освіти: загальнотеоретичні уявлення; конкретний навчальний предмет, навчальний матеріал 3 предмета; рівень педагогічної дійсності та структура особистості тощо [4, 114].

Однак, разом із численними розробками зміст професійної підготовки майбутніх фахівців сфери послуг в умовах освітньо-виробничого кластеру і пов'язані з ним питання щодо визначення його функціональних компонентів потребує подальшого дослідження і конкретизації.

Метою статті $\epsilon$ визначення складових професійної підготовки майбутніх фахівців сфери послуг як цілісної динамічної сукупності функціональних компонентів, виокремлених 3 урахуванням постіндустріальних тенденцій розвитку швейної галузі регіону.

Виклад основного матеріалу. На підставі аналізу традиційних і сучасних підходів до формування змісту освіти в наукових доробках вітчизняних і зарубіжних вчених та експертної оцінки учасників Запорізького регіонального освітньо-виробничого кластеру інноваційних швейних технологій нами до функціональних компонентів змісту професійної підготовки віднесено: предметно-понятійний, технологічний, праксиологічний, культурологічний, естетичний, морально-етичний, психологічний, екологічний, ресурсозбереження й енергоефективності, інформативно-комунікаційний.

Для більш чіткого уявлення про зміст об'єкту дослідження надаємо предметну характеристику кожному $з$ компонентів окремо.

Предметно-понятійний компонент охоплює знання, що дозволяють учням досконало володіти професійною термінологією. Опанування необхідними у професійній діяльності термінами розглядається як важливий фактор підвищення якості засвоєння навчального матеріалу, показником зорієнтованості майбутнього кравця в “теоретичних і прикладних аспектах предметної галузі професії”, що “забезпечує точність розуміння професійно значимої інформації в процесі виробничої діяльності” $[2,5]$.

Високий рівень професійної компетентності майбутніх фахівців сфери послуг передбачає розуміння нових тенденцій в соціальноекономічному розвитку суспільства, для чого необхідними $є$ знання основ філософії, ії законів і категорій, економічних теорій тощо. Так, до змісту навчального предмета "Основи галузевої економіки і підприємництва” вводяться терміни, що пояснюють закони спадної граничної корисності, ефективності виробництва, спадної віддачі, зростаючих альтернативних витрат; мотиваційної теорії очікування В. Врума та ін., які мають важливе значення для вивчення попиту на ринку товарів і послуг, регулювання результативності праці, визначення виробничих можливостей, посилення мотивації до продуктивної праці.

Технологічний компонент передбачає надання учням науково-технічної інформації з питань використання сучасних технологій виготовлення одягу, відомостей щодо провідних тенденцій у швейній промисловості, зокрема відхід від масового виробництва; виготовлення невеликих партій виробів цільним, безперервним 
процесом під прямим контролем замовника; індивідуальний пошив на високотехнологічній основі. У сучасному світі все більшого поширення набуває вироблення тканин $з$ використанням наукомістких технологій - “розумного” текстилю технічного, медичного, інформаційного, побутового призначення, тому окрема увага приділяється його властивостям. Високий рівень впровадження до складу різних видів швейного обладнання мікропроцесорної техніки, електроніки, удосконалення багатьох технічних операцій зумовило необхідність введення до змісту професійної підготовки навчального матеріалу, що містить відомості, технічні характеристики, особливості експлуатації швейного обладнання нового покоління. 3 метою надання майбутнім кравцям теоретичних знань, практичних умінь і навичок автоматичного проектування швейних виробів до змісту їх професійної підготовки внесені відомості щодо функціональних особливостей програми CAD ASSYST, їі головного меню (клавішами бічної панелі, рядком діалогу, вікном вимірювань тощо). Навчальний матеріал містить відомості щодо створення й редагування об'ємних зображень нових моделей на основі тривимірного манекена, зокрема: посадку одягу на фігурі; розподіл напруги тканини; колір, малюнок й фактуру тканин.

Праксиологічний (від гр. praktikos - діяльний, активний) компонент сприяє формуванню у майбутніх фахівців вміння конструктивно й результативно діяти в нових, невизначених, проблемних ситуаціях, використовуючи переваги сучасних технік і технологій. Враховуючи специфіку діяльності робітників легкої промисловості акцент у процесі професійної підготовки майбутніх фахівців сфери послуг робиться на тому, щоб активізувати позитивні потреби (вибудовувати дружні зв'язки з людьми, прагнути завоювати їх довіру; проявити повагу до інших людей, підтримувати їх, мати приклади для наслідування; прагнути успіху, виявляти наполегливість в усуненні перешкод на шляху до мети, у досягненні високих показників самовдосконалення, реалізувати свої таланти; надавати допомогу, проявляти турботу, альтруїзм, виявляти співчуття; прагнути впорядкованості, організованості, зрозумілості, охайності, акуратності, точності) й максимально нейтралізувати потреби негативного плану (ігнорувати інтереси інших людей, принижувати їх, виявляти агресію, жорстокість, презирство; ухилятися від труднощів; уникати уваги з боку оточуючих (відсутність ініціативи; острах поразки, невдачі); дистанціюватися від реального світу (небажання адекватно сприймати ситуацію). Зміст професійної підготовки кравців передбачає виявлення, формування й подальший розвиток характерних рис і якостей особистості, зорієнтованої на самоактуалізацію, що охоплює віру у свої сили; впевненість у собі; вміння використовувати досвід минулого; аналізувати; робити висновки; усвідомлювати значення своїх дій; виявляти ініціативність, переконливість, контактність, психологічну гнучкість, комунікабельність, стійкість до негативних зовнішніх впливів, працювати в команді тощо.

Культурологічний компонент змісту професійної підготовки розглядається як комплекс дидактичних і виховних засобів, спрямованих на розвиток особистості, які забезпечують активізацію суб'єкт-суб'єктних відносин в освітньому процесі; соціалізацію особистості; освоєння духовних цінностей і традицій країн, для яких ця мова $є$ рідною; сукупність психолінгвістичних аспектів вивчення мови, концентруючи ставлення людини до навколишнього світу і до самого себе. Наявність цього компоненту передбачає введення у зміст професійної підготовки майбутніх кравців відомостей щодо визначення загальних закономірностей виникнення, існування, формування і розвитку культури, iї значення для становлення особистості. Змістове наповнення культурологічного компоненту професійної підготовки майбутніх фахівців сфери послуг передбачає урахування функцій культури в суспільстві, зокрема: адаптаційної, комунікативної, інтегративної, функції соціалізації, а також інформаційної. Вагома частина змісту культурологічного компоненту націлена на оволодіння здобутками національної культури. Засвоєння учнями базових культурних цінностей дозволяє їм усвідомити свою соціокультурну приналежність, толерантно сприймати соціальну реальність як систему різноспрямованих тенденцій соціального руху.

Важливе значення у змісті професійної підготовки майбутніх фахівців сфери послуг має естетичний компонент, наявність якого передбачає залучення учнів до світу мистецтва. Це дозволяє розвивати та культивувати здібність інтелектуального уявлення, що є тим підгрунтям, на якому виникають особлива художня творчість, інтуїція, фантазія, творче уявлення кравця; розвивається і збагачується його особистісний, індивідуальний досвід світосприймання, розширюється вміння бачити і відчувати світ чужими очима. Естетизація професійної підготовки майбутніх кравців зорієнтована на 


\section{ЗМІСТФУНКЦІОНАЛЬНИХ КОМПОНЕНТІВПРОФЕСИЙНОӤ ПЦДОТОВКИМАЙБУТНІХ ФАХІВЦІВ СФЕРИ ПОСЛУГ В УМОВАХ ОСВІТНЬО-ВИРОБНИЧОГО КЛАСТЕРУ}

збереження у підлітків свого національного коріння, традицій народної творчості, що передбачає ознайомлення їх із пам'ятками історії, які несуть в собі інформацію етногенезу культури. Так, вивчаючи елементи українського народного одягу, учні отримують уявлення про естетичні уподобання предків українського народу.

Наявність у змісті професійної підготовки майбутніх фахівців сфери послуг моральноетичного компоненту орієнтує майбутніх кравців на усвідомлення таких цінностей, як моральна необхідність неухильного й чіткого виконання своїх професійних обов'язків, зумовлених специфікою даного виду професійної діяльності, зокрема вагомістю в ній людського фактору. А отже, важливого значення набувають емоційна витривалість, терпіння, стриманість, тактовність, чуйність, доброзичливість, привітність, душевна чемність. Учні беруть участь у розробленні еталону ідеального фахівця сфери послуг, спільно з викладачем виявляють складові зовнішнього вигляду ділової людини: костюм, зачіска, макіяж, аксесуари тощо; обговорюють доцільність визначення правил поведінки щодо культури побутового обслуговування замовників, необхідність формування професійно важливих якостей майбутніх кравців.

Оскільки кравець відноситься до типу професій “людина-людина" та “людина-художній образ” важливе значення у змісті професійної підготовки майбутніх фахівців сфери послуг має психологічний компонент, який передбачає володіння основами психології, прийомами невербального спілкування (мімікою, мовою жестів). Учні отримують уявлення про типи темпераменту (сангвінічний, холеричний, флегматичний, меланхолійний) та їх психологічні характеристики, що дозволить майбутнім фахівцям передбачати можливі реакції осіб 3 різним типом темпераменту і адекватно на них реагувати.

В основу екологічного компоненту змісту професійної підготовки кравців покладено погляди вченого-еколога Б. Коммонера на глобальну екосистему щодо “необхідності уважно прислуховуватися до природи, оскільки вона мудріша за людину, а також пам'ятати про неминучі наслідки кожної дії’. Відповідно до цього компоненту, учні отримують інформацію про сучасні технології, екологічно безпечні для оточуючого середовища; використання екологічно чистих матеріалів. У зв'язку з цим зміст предмета "Матеріалознавство” оновлено інформацією про смісові тканини (таслан, тісі, дюспо, таффета, меморі, оксфорд, тканини NC (нейлон, котон), ортон, грета, полікотон, сісу, тередо, саторі), при виробництві яких утворюється незначна частка відходів, шкода для навколишнього середовища $є$ мінімальною, а саме волокно - екологічно чистим. Для майбутніх фахівців сфери послуг важливо знати їхні особливості й характеристики для максимального використання у своїй професійній діяльності. Нерозривний зв'язок людини і оточуючого середовища виявляється у зорієнтованості швейного виробництва на поширення споживацьких властивостей одягу, одна 3 яких забезпечує підтримку комунікації в суспільстві незалежно від місцезнаходження через впровадження в одяг мікроелектромеханічних й електронних компонентів і систем. Посилення інтересу в суспільстві до названої тенденції зумовлює необхідність її висвітлення у змісті професійної підготовки майбугніх кравців, зокрема особливості використання “інтелектуального текстилю” (від англ. e-garment - електронний одяг, e- fabrics - електронні тканини, smart materials смарт-матеріали).

Компонент ресурсозбереження ци енергоефективності спрямований на ефективне використання сировини і основних матеріалів, оскільки ці витрати в структурі собівартості швейних виробів складають більше $80 \%$ і навіть незначне скорочення їх під час виробництва кожної одиниці продукції в ціломупо підприємству дає значний ефект. При конструюванні одягу враховуються тенденції живої природи в процесі свого розвитку прагнути до всебічної економії енергії, будівельного матеріалу і часу; 3'ясовуються фактори, що впливають на раціональне використання матеріалі (технологія і організація виробництва, властивості вихідної сировини, рівень технологічної дисципліни, технічна оснащеність тощо); розглядаються резерви в поліпшенні використання тканин. Орієнтація майбутніх кравців на енергоефективну професійну діяльність передбачає упроцесі їхньої підготовки посилення уваги до питань щодо використання технологічних відходів легкої промисловості і вторинних матеріальних ресурсів, що сприятиме максимальному використанню діючого виробничого потенціалу підприємств, зниженню матеріальних і паливно-енергетичних витрати на виготовлення виробів.

В умовах “інформаційного суспільства" важливого значення для формування професійної компетентності майбутніх фахівців сфери послуг набуває інформаційно-комунікативний компонент змісту їх професійної підготовки. Вітчизняні і 
зарубіжні вчені вказують на нерозривний зв'язок комунікації 3 інформацією підкреслює й наголошують, що “ефективність інформації сьогодні вимірюється, поряд з іншим, кількістю комунікативних дій, що можна зробити на їі основі” $[3,28]$. При цьому акцент робиться на тому, що сучасна інформація має фрагментарний характер, яка поділена на сегменти (кванти), що значно розширює можливості й перспективи від їі отримання. Учні вчаться систематизувати, узагальнити, структурувати отримані дані, надавати їм нові форми, візуальні (звукові) образи, вибудовувати аналогії тощо. Формується їх творча уява, образне мислення (імагінація); уміння ідентифікувати проблеми, відповідно до умов змінювати способи дії при вирішенні різного роду завдань (флексибільність - гнучкість інтелектуальних реакцій); здатність до рефлексії, самокритичності.

Отже, зміст професійної підготовки майбутніх фахівців сфери послуг в умовах освітньовиробничого кластеру розробляється 3 урахуванням вимог до їхньої професійно діяльності, а розглянуті компоненти $є$ тісно взаємопов' язаними між собою, взаємообумовлюють, взаємопередбачають та взаємопроникають одна в одну і складають основу формування професійної компетентності майбутніх працівників.

\section{ЛІТЕРАТУРА}

1. Богословский В.И., Глубокова Е.Н. Управление знаниями в образовательном процессе современного университета: науч.метод. материалы. Санкт Петербург, 2008. 288 с.

2. Бордовская Н.В., Кошкина Е.А. Терминологическая компетентность специалиста: проявление и уровни развития. Человек и образование. 2016. № 3 (48). C.4-11.

3. ГречкоП.К. Коммуникация и коммуникативность: различительное единство. Ценности и смысль. 2013. №4 (26). URL: https://cyberleninka.ru/article/ n/kommunikatsiya-i-kommunikativnost-razlichitelnoeedinstvo.

4. Ярмаченко М.Д. Стимулювання інтелектуального розвитку-важливатеоретичнапроблема й практичне завдання. Педагогіка і психологія. 1997. № 2. C. 243 .

5. Knipe C., Speck M. Why can't we get it right? Designing high-quality professional development for standards-based schools. 2nd ed. Thousand Oaks: Corwin Press, 2005. 156 p.

\section{REFERENCES}

1. Bogoslovskiy, V. I. \& Glubokova, Ye. N. (2008). Upravleniye znaniyami $v$ obrazovatelnom protsesse sovremennogo universiteta [Knowledge management in the educational process of the modern university]. The educational and methodological materials. St. Petersburg, 288 p. [in Russian].

2. Bordovskaya, N. V. \& Koshkina, Ye. A. (2016). Terminologicheskaya kompetentnost spetsialista: proyavleniye i urovni razvitiya [Terminological competence of a specialist: manifestation and levels of development]. A person and education. No. 3 (48), pp.4-11 [in Russian].

3. Grechko, P. K. (2013). Kommunikatsiya i kommunikativnost: razlichitelnoye yedinstvo [Communication and communication skills: distinctive unity]. Values and meanings. №4 (26). Available at: https://cyberleninka.ru/article/n/kommunikatsiya-ikommunikativnost-razlichitelnoe-edinstvo [in Russian].

4. Yarmachenko, M. D. (1997). Stymulyuvannya intelektualnoho rozvytku - vazhlyva teoretychna problema y praktychne zavdannya [Stimulation of intellectual development is an important theoretical problem and practical task]. Pedagogy and Psychology. No. 2, p.243 [in. Ukrainian].

5. Knipe, C. \& Speck, M. (2005). Why can't we get it right? Designing high-quality professional development for standards-based schools. 2nd ed. Thousand Oaks: Corwin Press, 156 p.[in English].

Стаття надійшла до редакції 11.04.2019

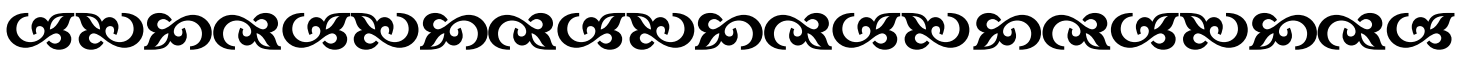

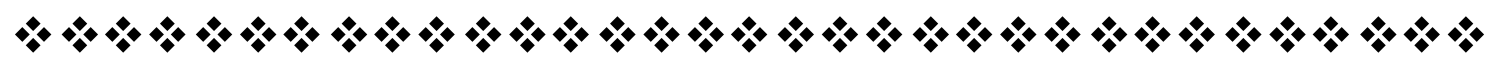

"Усе своє життя старанно навчайся. Кожен день ставай майстернішим, ніж ти був за день до иъого, а на наступний день - майстернішим, ніж сьогодні. Вдосқоналення не має кінияя".

Яммамото Нуунетомо білософ, письменник,

\section{$\% * \% * \%$

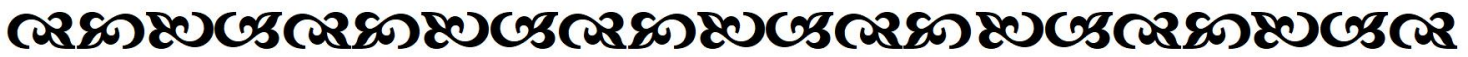

